\title{
Hepatoprotective effect Of Alhagi maurorum Bolss \\ (LEGUMINOSAE) ALCOHOLIC EXTRACT AGAINST HEPATOTOXICITY IN RATS
}

\author{
By \\ Maysa M. El Mallah \\ Nutrition and Food Sciences Department, \\ Faculty of Home Economics, \\ Helwan University
}

Research Gournal Specific Fducation

Faculty of Specific Education

gYansoura University

ISSUE NO. 44, OCTOBER. 2016

$$
\text { مجلة بحوث التربية النوعية - جامعة المنصورة }
$$




\title{
Hepatoprotective Effect of AlHagi MaURorum BoIsS (LEguminosaE) ALCOHOLIC EXTRACT AGAINST HEPATOTOXICITY IN RATS
}

\author{
Maysa M. El Mallah
}

\section{Abstract}

Alhagi maurorum (camel thorn plant) is a promising medicinal plant due to the presence of flavonoids and phenolic compounds as major contents of its constituents. This study was aimed to investigate the hepatoprotective effect of oral administration of alcoholic extract of Alhagi maurorum against CCl4-induced liver injury in rats after 4 weeks of treatment on serum levels of total cholesterol (TC), triglycerides (TG), lipoprotein fraction, alanine aminotransferase (ALT), aspartate aminotransferase (AST), alkaline phosphatase (ALP); total protein (TP),albumin, total bilirubin (TBil) and oxidative stress markers such as glutathione (GSH), Malondialdehyde (MDA), glutathione peroxidase (GPx), superoxide dismutase (SOD), catalase (CAT) were determined. Histopathological examination of liver was also performed .Forty two adult male (Sprague-Dawley strain) weighting $200+5 \mathrm{~g}$ were divided into six equal groups as follows: group1: negative control group, group 2: positive control (CCl4) group injected subcutaneously by a single dose of CCL4 (2 $\mathrm{ml} / \mathrm{kg} \mathrm{b.wt)} \mathrm{at} \mathrm{the} \mathrm{last} \mathrm{day} \mathrm{of} \mathrm{the} \mathrm{experiment,} \mathrm{group} \mathrm{3:} \mathrm{rats} \mathrm{treated} \mathrm{with}$ standard drug Silymarin (200 mg/kg b.wt) once daily for 4 weeks prior a single subcutaneous injection of CCL4 (2 ml/kg b.wt.) and groups (4), (5) and (6) were orally administered Alhagi maurorum alcoholic extract at doses of $(200,400$ and 600$) \mathrm{mg} / \mathrm{kg}$ b.wt once daily for 4 weeks prior a single subcutaneous injection of CCL4 $(2 \mathrm{ml} / \mathrm{kg}$ b.wt.) to induce experimental hepatotoxicity.The results showed that oral administration of Alhagi maurorum alcoholic extract in a concentrations of $600 \mathrm{mg} / \mathrm{kg} \mathrm{b}$.wt to rats for 4 weeks prior inducing hepatotoxicity by CCl4 significantly improved TC, TG, lipoprotein fractions, decreased the elevated serum levels

* Nutrition and Food Sciences Department, Faculty of Home Economics, Helwan University 
of liver enzymes (AST, ALT and ALP), total bilirubin and increased serum total protein when compared to the control positive group. Oxidative stress markers (MDA, GSH, GPx, SOD and CAT) were significantly improved as compared to the control positive group. Histopathological examination of liver section of rats orally given Alhagi maurorum alcoholic extract prior inducing hepatotoxicity by $\mathrm{CCl} 4$ showed alleviation of histological degeneration changes in protected groups compared to control positive group. It is concluded that Alhagi maurorum alcoholic extract has high hypolipidemic, hepatoprotective effect and antioxidant effects in $\mathrm{CCl} 4-$ intoxicated rats.

\section{Introduction}

Hepatotoxicity implies chemical-driven liver damage. Liver plays central role in transformation and clearance of most chemicals and is susceptible to the toxicity from these agents. Certain medicinal agents, when taken in overdoses and sometime even when introduced within therapeutic ranges, may injure the organ. Chemicals that cause liver injury are called hepatotoxins. (Park et al., 2009) Chemicals produce a wide variety of clinical and pathological hepatic injury. Biochemical markers (i.e. alanine transferase, alkaline phosphatase and bilirubin) are often used to indicate liver damage (Singal and Kumar 2009).

Liver damage is further characterized into hepatocellular (predominantly initial Alanine transferase elevation) and cholestatic type (initial alkaline phosphatase rise). However they are not mutually exclusive and mixed type of injuries are often encountered (Sibe et al., 2005). Chemicals and drugs such as Carbon tetrachloride (CCl4) catabolised radicals induced lipid peroxidation, damage the membranes of liver cells and organelles, causing the swelling and necrosis of hepatocytes and result to the release of cytosolic enzymes in to the blood (Mumoli et al., 2006) . A large number of medicinal plants have been shown hepatoprotective effects .Flavonoids and other phenolics of plant origin have been reported to have roles as scavengers and inhibitors of lipid peroxidation (Raju et al., 2008). In humans and higher animals, flavonoids have long been recognized to 
possess anti-inflammatory, antioxidant, ant-allergic and hepato-protective property (Xiao-feng et al., 2011). They are also believed to be antithrombotic, antibacterial, antifungal, antiviral, and cancer protective, and also to protect against cardiovascular disease (Ram ., 2013). Alhagi maurorum (Camel thorn) is a very common woody perennial shrub, rich in phenolic and flavonoid compounds with more than twelve different isolated flavonoids have been reported which are responsible for varied pharmacological and medicinal properties (Awaad et al., 2006).

Alhagi maurorum is in the family (Leguminosae) in the major group Angiosperms (Flowering plants). The perennial plant grows from a massive rhizome system which may extend over six feet into the ground. New shoots can appear over 20 feet from the parent plant. Above the ground, the plant rarely reaches four feet in height. It is a heavily branched, gray-green thicket with long spines along the branches. It bears small, bright pink to maroon pea flowers and small legume pods, which are brown or reddish and constricted between the seeds. The seeds are mottled brown beans (Atta and Abo El-Sooud 2004).

Alhagi maurorum known locally as "Camel's Thorn". It is widely distributed in Asia, the Middle East, Europe, and Africa. It is used in Saudi folk medicine for the treatment of liver problems, migraine, and cataract, as tonic, digestive, antipyretic, laxative, diuretic, aphrodisiac and antiinflammatory (Neamah.,2012). Alhagi maurorum species contains fatty acids, alkaloids, flavonoids, coumarins, tannins, sterols and ascorbic acid (Jalil et al., 2015).Seed oil is reported to contain unsaturated fatty acid $88 \%$ and a lot of microelements necessary for physiological functions (Lei.,2008).

A new flavonoid, isorhamnetin-3-O-[-alpha-1-rhamnopyranosyl-(1 -> 3)]-beta-D-glucopyranoside, along with two known flavonoids 3'-Omethylorobol (2) and quercetin 3-O-beta-d-glucopyranoside, was isolated from Alhagi maurorum. (Riaz et al., 2010). In addition, six main flavonoid glycosides were isolated from the ethanolic extract of $A$. maurorum (Marashdah, and Hazimi 2010). Moreover, A. maurorum roots contain lupeol (Beata et al., 2015) which is used as an antiangiogenic, antioxidative, 
and anti-inflammatory agent. It has been used as diaphoretic, diuretic, expectorant, and ulcer treatment (Shaker et al., 2010). Oil from its leaves was used for rheumatoid treatment and as laxative (Mohammad, and Seyyed., 2007) and (Laghari et al., 2011). Water extract of the roots is used to enlarge the ureter and to remove the kidney stones, whereas the methanolic extract is used as an antidiarrheal agent. (Ghane et al., 2008) .As herbal cough syrup (Hamed et al., 2012) . Very little scientific validation has been done on the whole plant materials of A. maurorum as a hepatoprotective agent until now. Therefore, the present study was aimed to evaluate the phenolic and flavonoid contents as well as hepatoprotective activity of Alhagi maurorum as one of flavonoids rich plant against carbon tetrachloride induced hepatotoxicity

\section{Materials and Methods}

\section{Materials}

\section{Alhagi maurorum Boiss (Leguminosae)}

Camel thorn plant (A. maurorum) was collected from Wadi El Natrun region (Egypt) after getting the agreement of the Director of Wilderness Areas in El-Beheira. The aerial parts of A. maurorum were collected, washed three times with tap water and two times with distilled water, dried in the shade, and milled to fine powder by Wiley mill (Model 4-GMI, Germany. still used for both Determination of phenolic compounds content and for preparation of alcohol extract.

\section{Rats and Basal Diet:}

Forty two male albino rats (Sprague-Dawley strain) weighting $200+5 \mathrm{~g}$ were obtained from the Laboratory Animal Colony, Helwan, Egypt. The rats were kept under controlled hygienic conditions in plastic cages and fed on the basal diet for one week before starting the experiment Basal diet constituents (Casein, cellulose, vitamin mixture, mineral mixture and choline chloride) were purchased from El-Gomhorya Company for Pharmaceutical and Chemical, Cairo, Egypt. 


\section{Carbon tetrachloride:}

Carbon tetrachloride (CCl4) was purchased from El Gomhorya Co., Egypt in the form of $40 \%$ liquid dispensed in $1 \mathrm{~L}$ plastic bottles.

\section{Silymarin tablets:}

Silymarin tablets were purchased from Sigma Chemical Co. St. Louis, MO., USA. All chemicals were of the highest analytical grade.

\section{Kits for biochemical analysis:}

All kits were purchased from Gamma Trade Company for Pharmaceutical and Chemicals, Dokki, Egypt.

\section{Methods}

\section{Preparation of plants extract:}

Alhagi maurorum. were powdered with a mechanical grinder to obtain a fine powder (200 gm.) the fine powder of whole flowers were packed in high quality filter paper, which was then subjected to successive extraction in a soxlet apparatus. The methanol extract was prepared by soaking $200 \mathrm{~g}$ of fine powder in 1 liter of $90 \%$ ethyl alcohol with daily shaking for 5 days and kept in a refrigerator. The ethanol was evaporated using a rotatory evaporator apparatus (manufactured in Russia) attached with a vacuum pump. Twenty grams of either extract (semisolid) were suspended in $100 \mathrm{ml}$ distilled water with $2 \mathrm{ml}$ of Tween 80 (suspending agent) to prepare a $20 \%$ alcoholic extract. (Kanchana and Nuannoi , 2012).

\section{Preliminary phytochemical screening of Alhagi maurorum Extract:}

Preliminary screening of of Alhagi maurorum extract was performed to investigate the presence or absence of the different phytochemical constituents such as phenolic, flavonoids, tannins, saponins and alkaloids using standard procedures described by (Harborne, 2007).

\section{Preparation of the basal diet:}

Basal diet was prepared according to Reeves et al., (1993). It consists of $20 \%$ protein (casein), $10 \%$ sucrose, $4 \%$ corn oil, $0.2 \%$ chlorine chloride, $1 \%$ vitamin mixture, $3.5 \%$ salt mixture , $5 \%$ fibers (cellulose) and the remainder was corn starch up to $100 \%$. 


\section{Induction of Hepatotoxicity:}

All animals, except normal control group, will be injected subcutaneously by a single dose of CCL4 ( $2 \mathrm{ml} / \mathrm{kg} \mathrm{b}$.wt) at the last day of experiment to induce acute hepatotoxicity according to the method described by Sundaresan and Subramanian ( 2003).

\section{Experiment and grouping of rats:}

All animals were housed at a controlled room temperature of $23 \pm 1{ }^{\circ} \mathrm{C}, 55 \%$ humidity and under a $12 \mathrm{~h}$ light/12-h dark schedule. The animals were fed on basal diet and water was provided ad libitum for one week before starting of the experiment for acclimatization. After one week adaptation period, the rats were randomly distributed into 6 equal groups, of 7 rats each. Group I was fed on basal diet and kept as a negative control group (normal rats).

Group (2): (Hepatotoxin group) Rats injected subcutaneously by a single dose of CCL4 ( $2 \mathrm{ml} / \mathrm{kg} \mathrm{b}$.wt) at the last day of experiment to induce acute hepatotoxicity (Sundaresan and Subramanian, 2003).

Group (3): orally given Silymarin in a dose of $200 \mathrm{mg} / \mathrm{kg}$ b.wt of for 4 weeks followed by injection subcutaneously by a single dose of CCL4 (2 $\mathrm{ml} / \mathrm{kg} \mathrm{b.wt)}$ at the last day of the experiment

Groups 4, 5 and 6 were orally given Alhagi maurorum extract (AME) in doses of 200, 400 and $600 \mathrm{mg} / \mathrm{kg}$ b.wt respectively towards the end of the experiment period rats were injected subcutaneously with CCl4(2 $\mathrm{ml} / \mathrm{kg} \mathrm{b.wt)}$. After $24 \mathrm{hrs}$ of CCl4 injection all animals were sacrificed, blood was collected to separate serum for biochemical analysis. Liver was excised out, washed in ice cold saline and small portion was fixed in $10 \%$ formalin for histopathological analysis and the other portion was frozen to homogenate.

\section{Biochemical Analysis}

Triglycerides (TG) was determined according to the method described by Trinder (1969), Total Cholesterol (TC) was determined according to the method described by Allain et al. (1974) and High Density 
Lipoprotein Cholesterol (HDL-C) concentrations were determined according to the method described by Lopes-Virella et al. (1977). Low Density Lipoprotein Cholesterol (LDL-C) concentration was calculated by using formula of Friedwald et al., (1972) .

\section{LDL-Cholesterol $=$ Total cholesterol $-(\mathrm{HDL}-\mathrm{C}+\mathrm{TG} / 5)$}

Activities of serum liver enzymes aspartate and alanine aminotransferases and alkaline phosphatase (AST, ALT and ALP) were chemically estimated according to Bergmeyer et al. (1978). total protein (TP),albumin, total bilirubin (TBil) were chemically determined as described by Burtis et al. (2006) . Serum uric acid was determined as described by Fossati et al. (1980). Serum creatinine concentrations were colorimetrically determined by the Jaffe reaction (Husdan and Rapoport, 1968).

\section{Lipid Peroxidation and Antioxidant Enzymes in Liver Tissues}

Liver homogenate was used for determination of tissue lipid peroxide (MDA), enzymatic (GPx, SOD and CAT) and non-enzymatic (GSH) antioxidants. Malondialdehyde was determined according to Ohkawa et al. (1979). The reduced glutathione (GSH) content in liver homogenate was determined colorimetrically by the method modified by Vaziri $\boldsymbol{e t}$ al., (2000). Activities of Glutathione Peroxidase (GPx), Superoxide Dismutase (SOD) and Catalase (CAT) antioxidant enzymes were determined chemically according to Paglia and Valentaine(1979) ; Spitz and Oberley(1989) and Sinha (1972) respectively.

\section{Histopathological Examination:}

Liver of the scarified rats was taken and immersed in $10 \%$ formalin solution. The fixed specimens were then trimmed washed and dehydrated in ascending grades of alcohol. Specimens were then cleared in xylol, embedded in paraffin, sectioned at 4-6 microns thickness and stained with Haemtoxylin and Eosin stain for histopathological examination as described by Carleton, (1979). 


\section{Statistical Analysis}

Statistical analysis was carried out using Statistical Package for the Social Sciences (SPSS) for Windows, version 20 (SPSS Inc., Chicago, IL, USA). Collected data was presented as mean \pm standard deviation (SD). Analysis of Variance (ANOVA) test was used for determining the significances among different groups according to Armitage et al. (2002). All differences were consider significant if $\mathrm{P} \cdot 0.05$.

\section{Results}

The phytochemical screening of Alhagi maurorum alcoholic extract (AMAE) revealed that it contains large amounts of Phenolic acids, flavonoids, and tannins ; moderate amounts of alkaloids Steroids and absence of the Anthraquinon, Saponin and Sterols as depicted in Table (1).

Table (1): phytochemical screen of Alhagi maurorum alcoholic extract

\begin{tabular}{||c|c|}
\hline Photochemical & Test result \\
\hline \hline Phenolics & +++ \\
\hline Flavonoids & +++ \\
\hline tannins & +++ \\
\hline Anthraquinon & - \\
\hline Alkaloids & ++ \\
\hline Saponin & - \\
\hline Sterols & - \\
\hline
\end{tabular}

The following symbol indicated the intensity of active compounds: absence of the constituents (-), a small amount $(+)$, a moderate amount $(++)$, and large amount (+++).

As shown in Table (2), rats injected subcutaneously with CCl4 (2 $\mathrm{ml} / \mathrm{kg}$ b.wt) in the last day of the experimental period had significant increases $(P<0.05)$ in serum levels of total cholesterol (TC), triglycerides (TG), low density lipoprotein (LDL) and decreased level of HDL -c (183. $59 \pm 4.14,120.35 \pm 2.25,126.85 \pm 0.05$ and $32.67 \pm 3.64 \mathrm{mg} / \mathrm{dl}$, respectively) when compared to the negative control group $(84.57 \pm 4.59,40.25 \pm 2.31$, $28, .51 \pm 1,22 \mathrm{mg} / \mathrm{dl}$ and $48.01 \pm 2.90 \mathrm{mg} / \mathrm{dl}$, respectively ) or with stander 
group $(86.32 \pm 1.32,40.98 \pm 1.41,30.13 \pm 0.02$ and $47.99 \pm 1.01 \mathrm{mg} / \mathrm{dl}$, respectively) . Pr-treated with Oral administration of Alhagi maurorum alcoholic extract at $(200,400$ and $600 \mathrm{mg} / \mathrm{kg})$ to rats intoxicated with a single subcutaneous injection of $\mathrm{CCl} 4$ at the last day of the experimental period caused a significant $(P<0.05$, ) decrease in the elevated serum TC, TG and LDL levels and increased serum HDL when compared to CCl4intoxicated group. Both of Silymarin and high dose of Alhagi maurorum alcoholic extract had the best effect near to the normal group.

Table(2): Effect of oral administration of Alhagi maurorum alcoholic extract on total cholesterol (TC), triglyceride (TG) LDL-C and HDL- C in rats injected S/C with $\mathrm{CCl} 4$ in the last day of the experimental period

\begin{tabular}{|c||c|c|c|c||}
\hline Groups & TC (mg/dL) & TG (mg/dL) & LDL(mg/dL) & HDL(mg/dL) \\
\hline \hline G1: Negative contro l (-ve ) & $84.57 \pm 4.59 \mathrm{~d}$ & $40.25 \pm 2.31 \mathrm{~d}$ & $28, .51 \pm 1,22 \mathrm{~d}$ & $48.01 \pm 2.90 \mathrm{a}$ \\
\hline G2:Positive control (+ve) & $183.59 \pm 4.14 \mathrm{a}$ & $120.35 \pm 2.25 \mathrm{a}$ & $126.85 \pm 0.05 \mathrm{a}$ & $32.67 \pm 3.64 \mathrm{~d}$ \\
\hline G3:Silymarin + CCl4 & $86.32 \pm 1.32 \mathrm{~d}$ & $40.98 \pm 1.41 \mathrm{~d}$ & $30.13 \pm 0.02 \mathrm{~d}$ & $47.99 \pm 1.01 \mathrm{a}$ \\
\hline G4: AMAE at $\mathbf{( 2 0 0 m l / k g ~ b . w t ) + \mathbf { C C l 4 }}$ & $162.82 \pm 3.13 \mathrm{~b}$ & $105.64 \pm 1.11 \mathrm{~b}$ & $105.35 \pm 0.06 \mathrm{~b}$ & $36.34 \pm 2.21 \mathrm{c}$ \\
\hline G5: AMAE at $\mathbf{( 4 0 0 m l / k g ~ b . w t ) + \mathbf { C C l 4 }}$ & $130.35 \pm 1.17 \mathrm{c}$ & $74.91 \pm 3.51 \mathrm{c}$ & $75.16 \pm 0.06 \mathrm{c}$ & $40.21 \pm 1.10 \mathrm{~b}$ \\
\hline G6: AMAE at $\mathbf{( 6 0 0 m l / k g ~ b . w t ) + \mathbf { C C l 4 }}$ & $89.52 \pm 1.97 \mathrm{~d}$ & $43.15 \pm 2.73 \mathrm{~d}$ & $34.76 . \pm 0.07 \mathrm{~d}$ & $46.13 \pm 2.13 \mathrm{a}$ \\
\hline \hline
\end{tabular}

Data are presented as means \pm standard deviation, ( $\mathrm{n}=7$ for each group) .Values with different superscripts within the column are significantly different at $\mathrm{P}<0.05$. Values with similar or partially similar superscripts are non-significant.

From data recorded in Table (3) it could be noticed that rats acutely intoxicated by a single subcutaneous injection of $\mathrm{CCl} 4$ at the last day of the experimental period had significant $(\mathrm{P}<0.05)$ increases $(P<0.05)$ in the serum activities of AST, ALT and ALP enzymes (140.22 \pm 0.21 , $120.81 \pm 0.22$ and133.53 $\pm 1.55 \mathrm{U} / \mathrm{L}$, respectively) as compared to control (ve) group $(52.22 \pm 1.36,49.04 \pm 0.36$ and $59.77 \pm 8.90 \mathrm{U} / \mathrm{L}$, respectively) or with stander group(53.45 $\pm 2.44,51.01 \pm 0.13$ and $59.01 \pm 1.34)$. Administration of Alhagi maurorum alcoholic extract at (200, 400 and 600 $\mathrm{mg} / \mathrm{kg} \mathrm{b}$. wt) for four weeks before subcutaneous injection of $\mathrm{CCl} 4$ induced significant decrease $(\mathrm{P}<0.05)$ in all the elevated serum marker levels of AST, ALT, ALP, when compared to the hepatotoxic rats (control+v group). 
Intoxicated rats pre treated with the large dose $(600 \mathrm{mg} / \mathrm{kg} \mathrm{b}$. wt) of Alhagi maurorum alcoholic extract(AMAE) caused the highest reduction of hepatotoxicity in the elevated serum liver enzymes AST,ALT and ALP enzymes ( $60.52 \pm 1.78,55.29 \pm 0.46$ and $55.29 \pm 0.46 \mathrm{U} / \mathrm{L}$, respectively) compared to $\mathrm{CCl} 4$-intoxicated group (+ ve) group.

Table (3): Effect of oral administration of Alhagi maurorum alcoholic extract on serum liver enzyme AST, ALT and ALP in rats injected S/C with $\mathrm{CCl} 4$ in the last day of the experimental period

\begin{tabular}{|c|c|c|c|}
\hline Groups & $\operatorname{AST}(\mathbf{U} / \mathbf{L})$ & $\mathbf{A L T}(\mathbf{U} / \mathbf{L})$ & $\mathbf{A L P}(\mathbf{U} / \mathbf{L})$ \\
\hline G1: Negative contro I (-ve ) & $52.22 \pm 1.36 \mathrm{e}$ & $49.04 \pm 0.36 \mathrm{e}$ & $59.77 \pm 8.90 \mathrm{e}$ \\
\hline G2:Positive control (+ve) & $140.22 \pm 0.21 \mathrm{a}$ & $120.81 \pm 0.22 \mathrm{a}$ & $133.53 \pm 1.55 \mathrm{a}$ \\
\hline G3:Silymarin + CCl4 & $53.45 \pm 2.44 \mathrm{e}$ & $51.01 \pm 0.13 \mathrm{de}$ & $59.01 \pm 1.34 \mathrm{e}$ \\
\hline G4: AMAE at $(200 \mathrm{ml} / \mathrm{kg}$ b.wt $)+\mathrm{CCl} 4$ & $104.23 \pm 4.76 \mathrm{~b}$ & $100.15 \pm 0.48 \mathrm{~b}$ & $102.21 \pm 21.78 \mathrm{~b}$ \\
\hline G5: AMAE at $(400 \mathrm{ml} / \mathrm{kg}$ b.wt $)+\mathrm{CCl} 4$ & $79.58 \pm 3.43 \mathrm{c}$ & $69.37 \pm 0.33 \mathrm{c}$ & $80.45 \pm 14.91 \mathrm{c}$ \\
\hline G6: AMAE at $(600 \mathrm{ml} / \mathrm{kg}$ b.wt $)+\mathrm{CCl} 4$ & $60.52 \pm 1.78 \mathrm{~d}$ & $55.29 \pm 0.46 \mathrm{~d}$ & $66.64 \pm 1.51 \mathrm{~d}$ \\
\hline
\end{tabular}

Data are presented as means \pm standard deviation, ( $\mathrm{n}=7$ for each group) Values with different superscripts within the column are significantly different at $\mathrm{P}<0.05$. Values with similar or partially similar superscripts are non-significant.

Results in Table (4) explained that a single subcutaneous injection of $\mathrm{CCl} 4$ to male rats at the last day of the experimental period (control positive group) induced a significant liver damage which observed from a significant decrease (P 0.05) in both total protein (TP), and albumin and increase in the level of serum total bilirubin $(5.31 \pm 1.2,2.99 \pm 0.12$ and $9.42 \pm 1.76 \mathrm{~g} / \mathrm{dL}$ respectively) compared with control negative group $(8.95 \pm 1.32,4.43 \pm 0.02$ and5.53 $\pm 1.78 \mathrm{~g} / \mathrm{dL}$ respectively) . Rats orally given Alhagi maurorum alcoholic extract(AMAE) (200, 400 and $600 \mathrm{mg} / \mathrm{kg} \mathrm{b}$. wt) for 4weeks and injected with $\mathrm{CCl} 4$ subcutaneously at the last day of the experiment showed elevation in serum TP, Albumin and decrease in bilirubin level. The highest protection was observed in both intoxicated rats pretreated with Silymarin $(8.66 \pm 1.73,4.15 \pm 0.32$ and $6.17 \pm 1.94 \mathrm{~g} / \mathrm{dL}$ respectively) and the group of intoxicated rats pretreated with Alhagi maurorum alcoholic extract (AMAE) in a dose of $600 \mathrm{mg} / \mathrm{kg}$ b.wt., $(8.17 \pm 15.51,3.93 \pm 0.11$ and $6.31 \pm 1.45 \mathrm{~g} / \mathrm{dL}$ 
respectively) compared with control positive group (+ve) (5.31 \pm 1.2 , $2.99 \pm 0.12$ and $9.42 \pm 1.76 \mathrm{~g} / \mathrm{dL}$ respectively).

Table (4): Effect of oral administration of Alhagi maurorum alcoholic extract (AMAE) on total protein, total bilirubin and albumin in rats injected S/C with CCl4 in the last day of the experimental period

\begin{tabular}{||l||c|c|c||}
\hline \multicolumn{1}{|c|}{ Groups } & $\begin{array}{c}\text { Total protein } \\
(\mathbf{g} / \mathbf{d L})\end{array}$ & $\begin{array}{c}\text { Albiumin } \\
(\mathbf{g} / \mathbf{d L})\end{array}$ & $\begin{array}{c}\text { Total bilirubin } \\
(\mathbf{g} / \mathbf{d L})\end{array}$ \\
\hline \hline G1: Negative contro l (-ve $)$ & $8.95 \pm 1.32 \mathrm{a}$ & $4.43 \pm 0.02 \mathrm{a}$ & $5.53 \pm 1.78 \mathrm{~d}$ \\
\hline G2:Positive control (+ve) & $5.31 \pm 1.2 \mathrm{~d}$ & $2.99 \pm 0.12 \mathrm{c}$ & $9.42 \pm 1.76 \mathrm{a}$ \\
\hline G3:Silymarin + CCl4 & $8.66 \pm 1.73 \mathrm{a}$ & $4.15 \pm 0.32 \mathrm{~b}$ & $6.17 \pm 1.94 \mathrm{c}$ \\
\hline G4: AMAE at $\mathbf{( 2 0 0 m l / k g ~ b . w t ) + \mathbf { C C l 4 }}$ & $7.12 \pm 11.15 \mathrm{~b}$ & $3.17 \pm 0.04 \mathrm{~b}$ & $7.99 \pm 0.83 \mathrm{~b}$ \\
\hline G5: AMAE at $\mathbf{4 0 0 m l / k g ~ b . w t ) + \mathbf { C C l 4 }}$ & $7.61 \pm 10.01 \mathrm{~b}$ & $3.35 \pm 0.04 \mathrm{~b}$ & $7.32 \pm 0.74 \mathrm{~b}$ \\
\hline G6: AMAE at $\mathbf{( 6 0 0 m l / k g ~ b . w t ) + \mathbf { C C l 4 }}$ & $8.17 \pm 15.51 \mathrm{a}$ & $3.93 \pm 0.11 \mathrm{~b}$ & $6.31 \pm 1.45 \mathrm{c}$ \\
\hline \hline
\end{tabular}

Data are presented as means \pm standard deviation, ( $\mathrm{n}=7$ for each group) Values with different superscripts within the column are significantly different at $\mathrm{P}<0.05$. Values with similar or partially similar superscripts are non-significant.

Data illustrated in table (5) showed that rats subcutaneously injected with a single dose of $\mathrm{CCl} 4$ at the last day of the experimental period (+ve) had significant decrease in antioxidant enzymes activity (glutathione peroxidase (GPx), superoxide dismutase (SOD) and catalase (CAT)) and also in non-enzymatic (GSH) antioxidant system in liver tissue and enhanced the end product of lipid peroxidation (MDA) level in liver tissues as compared with the negative control group. Oral administration of Alhagi maurorum alcoholic extract (AMAE) at (200, 400 and $600 \mathrm{mg} / \mathrm{kg}$ ) or Silymarin group for four weeks and injected with a single dose of CCl4 at the last day of the experimental period showed significant increase in both of the enzymatic (GPX), (SOD) , (CAT) and non-enzymatic (GSH) antioxidant systems in liver tissue, while the elevated (MDA) levels were found to be reduced back towards the normal level in pretreated rats given the highest dose of Alhagi maurorum alcoholic extract as well as intoxicated rats pretreated with Silymarin. The level of antioxidant enzyme was significantly improved by administration of $600 \mathrm{mg} / \mathrm{kg}$ b.wt of Alhagi 
maurorum extract and in Silymarin treated rats intoxicated with $\mathrm{CCl} 4$ at the last day of the experimental period.

Table (5): Effect of oral administration of Alhagi maurorum alcoholic extract on GPX,SOD ,CAT,GSH and MDA in rats injected S/C with CCl4 in the last day of the experimental period

\begin{tabular}{|c|c|c|c|c|c|}
\hline Groups & $\begin{array}{c}\text { GPx } \\
(\mathbf{U} / \mathbf{m g})\end{array}$ & $\begin{array}{c}\text { SOD } \\
(\mathrm{U} / \mathrm{mg})\end{array}$ & $\begin{array}{c}\text { CAT } \\
(\mathrm{U} / \mathrm{mg})\end{array}$ & $\begin{array}{c}\text { MDA } \\
(\mu \mathrm{mol} / \mathrm{dl}\end{array}$ & $\begin{array}{c}\text { GSH } \\
(\mu \mathrm{mol} / \mathrm{dl}\end{array}$ \\
\hline G1: Negative contro l (-ve ) & $\begin{array}{c}53.44 \pm \\
3.33 \mathrm{a} \\
\end{array}$ & $\begin{array}{l}85.22 \pm \\
1.25 \mathrm{a} \\
\end{array}$ & $\begin{array}{c}74.35 \pm \\
0.97 \mathrm{a} \\
\end{array}$ & $\begin{array}{l}10.55 \pm \\
1.02 \mathrm{~d}\end{array}$ & $\begin{array}{l}4.72 \pm \\
0.02 \mathrm{a}\end{array}$ \\
\hline G2:Positive control (+ve) & $\begin{array}{c}25.19 \pm \\
1.33 \mathrm{~d}\end{array}$ & $\begin{array}{c}43.43 \pm \\
1.81 \mathrm{e}\end{array}$ & $\begin{array}{c}35.54 \pm \\
1.76 \mathrm{e}\end{array}$ & $\begin{array}{c}21.99 \pm \\
1.01 \mathrm{a}\end{array}$ & $\begin{array}{l}2.54 \pm \\
0.01 \mathrm{~d}\end{array}$ \\
\hline G3:Silymarin + CCl4 & $\begin{array}{c}50.02 \pm \\
2.31 \mathrm{a} \\
\end{array}$ & $\begin{array}{c}85.55 \pm \\
1.32 \mathrm{a} \\
\end{array}$ & $\begin{array}{r}73.15 \\
\pm 1.01 \mathrm{a} \\
\end{array}$ & $\begin{array}{l}13.61 \pm \\
1.02 \mathrm{~cd}\end{array}$ & $\begin{array}{l}4.32 \pm \\
0.03 \mathrm{a}\end{array}$ \\
\hline G4: AMAE at $(200 \mathrm{ml} / \mathrm{kg}$ b.wt $)+\mathrm{CCl} 4$ & $\begin{array}{c}42.42 \pm \\
1.12 \mathrm{c}\end{array}$ & $\begin{array}{l}56.18 \pm \\
1.43 \mathrm{~d}\end{array}$ & $\begin{array}{c}35.45 \pm \\
2.16 \mathrm{~d}\end{array}$ & $\begin{array}{l}18.02 \pm \\
1.04 \mathrm{~b}\end{array}$ & $\begin{array}{l}3.16 \pm \\
0.17 b c\end{array}$ \\
\hline G5: AMAE at $(400 \mathrm{ml} / \mathrm{kg}$ b.wt $)+\mathrm{CCl} 4$ & $\begin{array}{c}42.33 \pm \\
1.16 \mathrm{c} \\
\end{array}$ & $\begin{array}{c}68.25 \pm \\
1.32 \mathrm{c} \\
\end{array}$ & $\begin{array}{c}49.01 \pm \\
1.36 \mathrm{c} \\
\end{array}$ & $\begin{array}{l}17.92 \pm \\
1.02 b c\end{array}$ & $\begin{array}{l}3.75 \pm \\
0.10 \mathrm{~b}\end{array}$ \\
\hline G6: AMAE at $(600 \mathrm{ml} / \mathrm{kg}$ b.wt $)+\mathrm{CCl} 4$ & $\begin{array}{l}45.15 . \pm \\
4.23 \mathrm{a} \mathrm{b}\end{array}$ & $\begin{array}{c}80.75 \pm \\
2.11 \mathrm{~b}\end{array}$ & $\begin{array}{l}71.80 \pm \\
2.31 \mathrm{ab}\end{array}$ & $\begin{array}{c}15.42 \pm \\
1.04 \mathrm{c}\end{array}$ & $\begin{array}{l}4.34 \pm \\
0.01 \mathrm{a}\end{array}$ \\
\hline
\end{tabular}

Data are presented as means \pm standard deviation, $(n=7$ for each group) Values with different superscripts within the column are significantly different at $\mathrm{P}<0.05$.Values with similar or partially similar superscripts are non-significant.

\section{Histopathological studies}

Histopathological examination showed no histological change in the liver structure of normal control rats (Photo.1). Hepatic intense centrilobular, necrosis, vacuolization and macro vesicular fatty changes were observed in the liver sections of rats subcutaneously injected with a single dose of $\mathrm{CCl} 4$ at the last day of the experimental period (control positive group) (Photo.2). Examined liver sections of rats orally given standard drug, silymarin and intoxicated with $\mathrm{CCl} 4$ at the last day of the 
experimental period showed normal hepatocyte (Photo.3). .The intoxicated animals pretreated with different doses of Alhagi maurorum alcoholic extract showed recovering of hepatocyte, as follow. The pretreated with Alhagi maurorum alcoholic extract at $200 \mathrm{mg} / \mathrm{kg}$ b.wt, shows a moderate number of recovered hepatocyte with a small amount of necrosis, vacuolization and macro vesicular fatty changes ((Photo.4). While the 400 $\mathrm{mg} / \mathrm{kg}$ b.wt -treated group, showed minimal inflammation and near-normal architecture possessing higher hepatoprotective activity ((Photo.5).The liver sections of the intoxicated animals pretreated with Alhagi maurorum alcoholic extract at $600 \mathrm{mg} / \mathrm{kg}$ b.wt., exhibited significant liver protection against $\mathrm{CCl}_{4}$ as evident by the presence of normal hepatic cords, absence of necrosis and fatty infiltration, supplementing the protective effect (Photo.6).

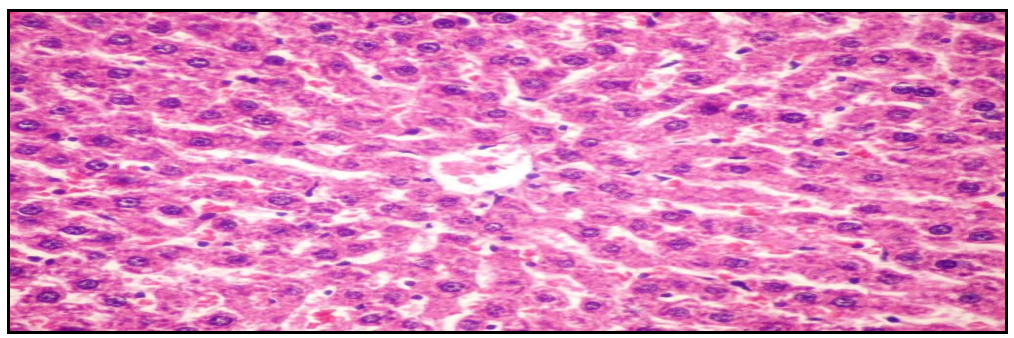

Photo. (1): Liver of the negative control rat showing the normal histological structure of hepatic cells. (H and E x 400).

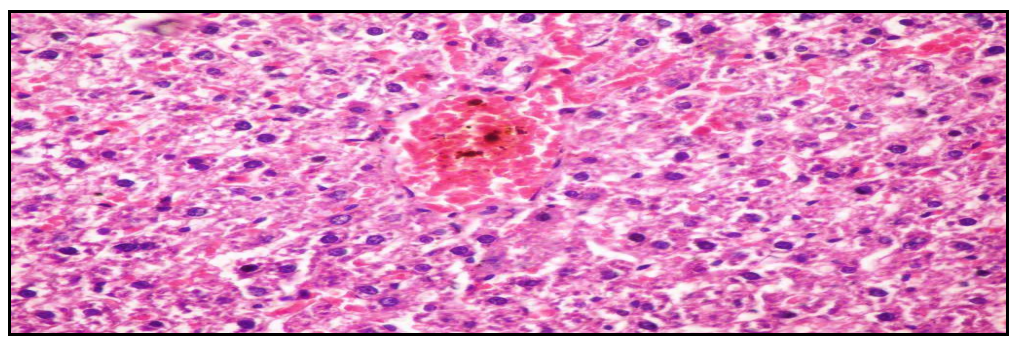

Photo. (2): Liver of intoxicated rats (non-treated) (+ve) rat showing congestion of hepatic central vein (Arrow) (H and E x 400). 


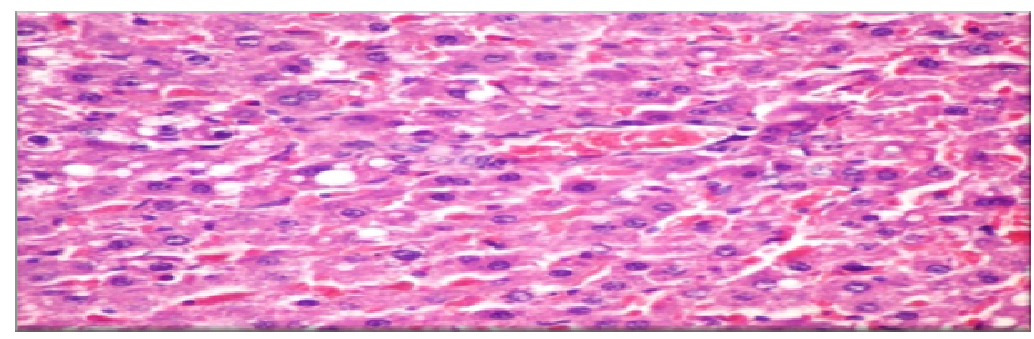

Photo. (3): Liver of intoxicated rats of Pretreated group with Silymarin showing normal hepatocytes (arrow mark) with central vein (H and E x 400).

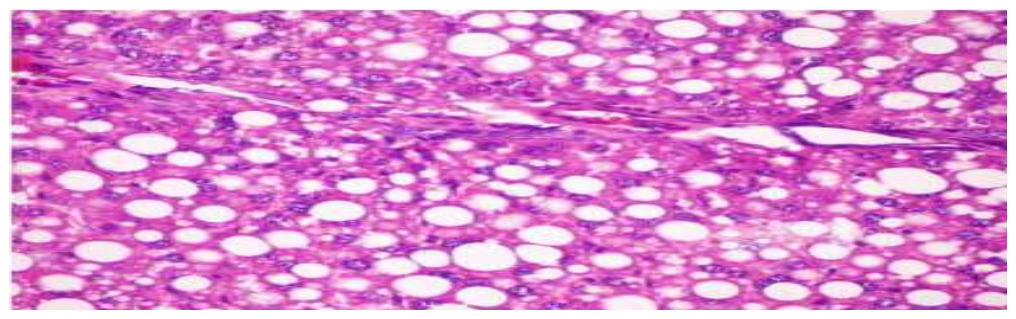

Photo. (4): Liver of intoxicated rats of pretreated group with Alhagi maurorum alcoholic extract in a dose of $200 \mathrm{mg} / \mathrm{kg}$ showing a moderate number of recovered hepatocytes with a small amount of necrosis, vacuolization and macrovesicular fatty changes (H and E x 400).

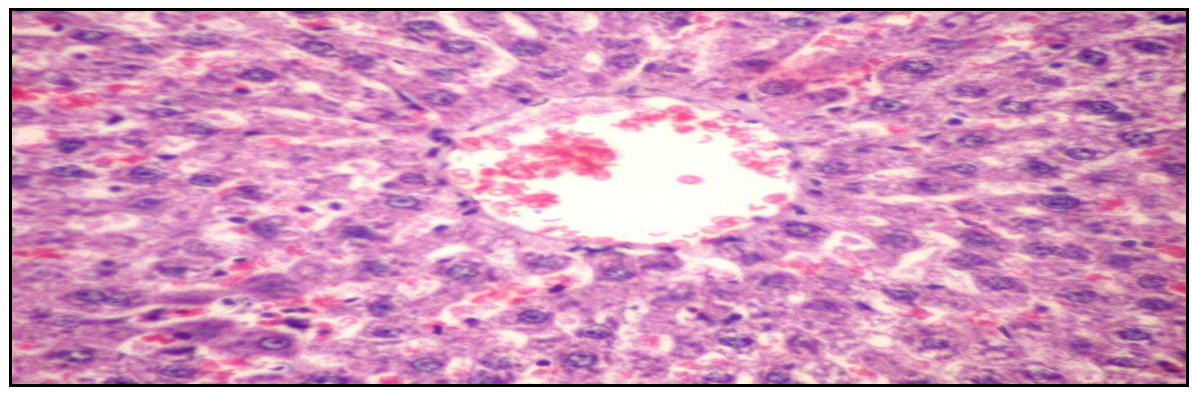

Photo. (5): Liver of intoxicated rats pretreated with Alhagi maurorum alcoholic extract in a dose of $400 \mathrm{mg} / \mathrm{kg}$ showing minimal inflammation and near-normal architecture possessing higher hepatoprotective activity 


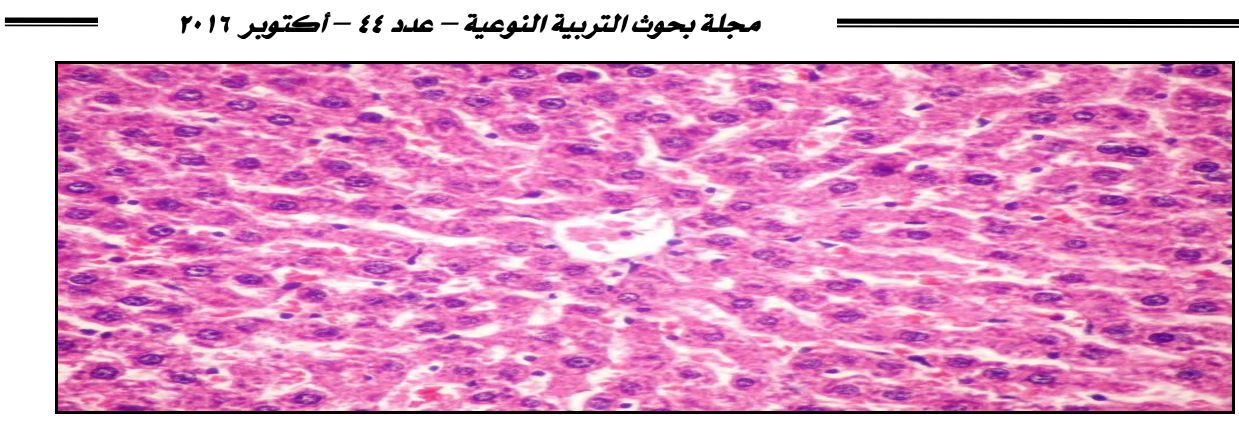

Photo. (6): Liver of intoxicated rats pretreated with Alhagi maurorum alcoholic extract in a dose of $600 \mathrm{mg} / \mathrm{kg}$ showing Significant protection evident by the presence of normal hepatic cords, absence of necrosis and fatty infiltration, supplementing the protective effect.

\section{Discussion}

Hepatotoxicity implies chemicaldriven liver damage. Liver plays central role in transformation and clearance of most chemicals and is susceptible to the toxicity from these agents.Certain medicinal agents, when taken in overdoses and sometime even when introduced within therapeutic ranges, may injure the organ. Chemicals that cause liver injury are called hepatotoxins (Tavga et al., 2009).

Chemicals and drugs such as Carbon tetrachloride (CCl4) established radicals induced lipid peroxidation, damage the membranes of liver cells and organelles, causing the swelling and necrosis of hepatocytes and result to the release of cytosolic enzymes in to the blood (Khan et al., 2011). A large number of medicinal plants have been shown hepatoprotective.Flavonoids and other phenolics of plant origin have been reported to have roles as scavengers and inhibitors of lipid peroxidation (Bhattacharyya, et al., 2003). In this study, the phytochemical screening of Alhagi maurorum alcoholic extract showed that it contain Phenolic acids ,flavonoids, alkaloids, , and, these results were in accordance with those previously reported.

Liver injury induced by $\mathrm{CCl} 4$ is the best characterized system of xenobiotic -induced hepatotoxicity and is commonly used models for the screening of anti-hepatotoxic and/or hepatoprotective activities of drugs .The changes associated with $\mathrm{CCl} 4$ induced liver damage are similar to that 
of acute viral hepatitis (Masuda, 2006). Carbon tetrachloride accumulates in hepatic parenchymal cells and metabolized by cytochrome P-450 enzyme and its metabolic product; trichloromethyl free radicals $(\mathrm{CCl} 3)$ These free radicals are highly reactive, alkylate cellular proteins and other macromolecules with a simultaneous attack on polyunsaturated fatty acids in the presence of oxygen to produce lipid peroxides, leading to liver damage. Lipid peroxidation will initiate pathological changes such as depression of protein synthesis Park et al., (2009).

In the current study the results revealed that intoxicated rats with CCl4 resulted in significant increase in serum level of total cholesterol (TC), triglycerides (TG), low density lipoprotein cholesterol (LDL-c) accompanied with a significant decrease in high density lipoprotein cholesterol (HDL-c) level as compared to the negative control group. Our results in agreement with (El-Habibi et al., 2009) and (Al-Dosari, 2010) who reported that there was an increase in the levels of cholesterol, triglycerides, and free fatty acids in plasma and tissues of rats intoxicated with $\mathrm{CCl} 4$ these results might be due to an increase in the synthesis of fatty acids and triglycerides from acetate which is responsible for the transport of acetate into the liver cell, resulting in increased substrate (acetate) availability or it could be due to increase the synthesis of cholesterol.

The effect of flavonoids and flavonoid rich extracts on reducing lipid levels effectively has been reported in several studies (Anila and Vijayalakshmi, 2002). Silymarin, a flavonolignan has been widely used from ancient times to treat liver disorders, including acute and chronic viral hepatitis, toxin/drug-induced hepatitis and cirrhosis/alcoholic liver diseases (Hussein et al.,2006 ). In the present study intoxicated rats pretreated with silymarin significantly reduced serum total cholesterol, LDL-cholesterol and triglycerides with elevation of HDL $-\mathrm{C}$.

In the current study Pretreatment of rats with Alhagi maurorum alcoholic extract resulted in significant improvement in the tested lipid profile parameters, that could be attributed to an increase in the inhibition of intestinal absorption of cholesterol, interference with lipoprotein production 
increased expression of hepatic LDL receptor and their protection, leading to an increased removal of LDL-C from the blood and its increased degradation and catabolism of cholesterol from the body. All these events either individually or in combination lead to decrease in serum LDL-C levels, which reduced serum total cholesterol level during the pretreatment (Laghari et al., 2011). This improvement might be due to the presence of lupeol, a component of A. maurorum extract, which plays an important role in normalization of lipid profile (Sudhahar et al., 2007)

Assessment of liver function can be performed by determining the activity of serum enzymes AST, ALT and ALP, originally present in high concentrations in the cytoplasm. When there is hepatic injury, these enzymes leak into the blood stream in conformity with the extent of liver damage (Krasteva et al., 2007 and $\mathrm{Xu}$ et al.,2007).Total bilirubin (TBil) and total protein (TP) levels on other hand are related to the function of hepatic cell (Ismet et al., 2013). In the present study, the hepatotoxicity of CC14 in rats was confirmed by a significant elevation of AST, ALT, ALP and total bilirubin. In addition, CC14 intoxication produced a significant reduction in plasma total protein level. This may be due to release of these enzymes from the cytoplasm into the blood rapidly after cellular damage and a reduction in hepatic protein synthesis. Liu et al., (2013) reported that elevation of AST, ALT and ALP in response to CCl4 could be attributed to hepatic structural damage because these enzymes are normally localized to the cytoplasm and are released into the circulation after cellular damage has occurred.

The results of the present study showed that, intoxicated rats pretreated with Alhagi maurorum alcoholic extract had an effective improvement in liver function and afforded a protection against $\mathrm{CCl} 4$ induced hepatocyte toxicity. This was manifested by decreasing in elevated enzymes leakage of (ALT, AST, and ALP) and total bilirubin level and increasing total protein and albumin as compared with, CCl4-intoxicated group. The hepatoprotective effect of Alhagi maurorum alcoholic extract may be attributed to a significant free radical scavenging and antioxidant activity as mentioned by (Shaker et al .2010) and (Jalil et al., 2015) who mentioned that Alhagi maurorum alcoholic extract is rich in a variety of 
bioactive metabolites including flavonoids and terpenoids. These bioactive ingredients have potent activities for scavenger the Superoxide radicals $(\mathrm{O}$ (2) $\left(*_{-}\right)$) and hydroxyl radicals ( $\left.\mathrm{HO}(*)\right)$ resulted from CCl4 metablites (Riaz et al., 2010). As well as the reference drug Silymarin significantly reduced the elevation in the activities of these enzymes (Hussein et al., 2006) . Effects of silymarin might be due to its antioxidant and free radical scavenging properties.

Histopathological observations of the liver of CCl4- administered rats showed revealed presence of hepatic intense centrilobular, necrosis, vacuolization and macro vesicular fatty changes. These results were in harmony with the previous data reported by (Zalatnai et al., 1991 and Candasamy 2010). A. maurorum possesses flavonoids and tannins which were confirmed by phytochemical analysis of the extract and these both groups are well recognized for their hepatoprotective action. Saponins, alkaloids, flavonoids and triterpenoids are phytochemical constituents of A. maurorum possessing antioxidant, free radical scavenging ability and inhibition of lipid peroxidation, by hydroxyl groups present in these compounds (Djeridane et al., 2006).

In the present study, a significant elevation of malondialdehyde (MDA) (lipid peroxidation product) accompanied by lower activities of the antioxidant enzymes, catalase (CAT), superoxide dismutase (SOD), glutathione peroxidase (GPx) and glutathione (GSH) had been observed in the liver tissue of CCl4-treated group compared to control negative group. The decreased activities of the antioxidative enzymes probably occurred as a result of free radical production and the excessive use of these enzymes. These results were in accordance with the result previously reported by (Baravalia et al., 2011). Evidence of lipid peroxidation by increased MDA level is one of the primary means of associated oxidative processes with an overall decrease in cellular function (Rosenblat $\boldsymbol{e t}$ al., 2006). The increase in malondialdehyde (MDA) levels in liver suggests enhanced lipid peroxidation leading to tissue damage and failure of antioxidant defense mechanism to prevent formation of excessive free radicals (shnakumari $\boldsymbol{e t}$ al., 2012). 
With regard to the hepatprotective effect of Alhagi maurorum alcoholic extract when orally administered to rats at (200, 400 and $600 \mathrm{mg}$ $/ \mathrm{kg}$ b. wt) for 4 weeks before a single subcutaneous injection of $\mathrm{CCl} 4$ at the last day of the experimental period on MDA, GSH, CAT, SOD and GPx, the results revealed that pretreatment with Alhagi maurorum alcoholic extract significantly reduced MDA and increased levels of GSH, accompanied by increase activities of the antioxidant enzymes, CAT, SOD, GPx compared to control positive group. These findings might be due to antioxidant activity of Alhagi maurorum alcoholic extract These result was confirmed by (Monica et al ., 2014), (Beata et al., 2015) and (Lei et al ., 2008) who mentioned that, raised levels of GSH have been reported to elicit a protective response against the toxic manifestations of chemicals, particularly those involving oxidative stress . (Riaz et al., 2010) reported that, oral administration of Alhagi maurorum alcoholic extract inhibited superoxide generation in macrophages in rats . Alhagi maurorum alcoholic extract significantly increased both of catalase (CTA) and Glutathione reductase levels in blood and liver, whereas glutathione peroxidase was found to be decreased (Ram .,2013) .

The biochemical results of our study were confirmed by histopathological findings, which seen in liver sections. The histological findings of liver of pretreated rats with Alhagi maurorum alcoholic extract showed almost completely normal structure with mild fibroblastic proliferation and sporadic cell necrosis.. Oval cell hyperplasia in the portal area was very clear and necrosis was more reduced than CCl4- intoxicated rats fed on basal diet, thus may be explained by antioxidant activity of Alhagi maurorum alcoholic extract that may be attributed to its constituents of phytochemical. These histological findings agreed with the study of (Khan and Ahmed 2009) who reported that the oxidative damage to tissue and their cellular component can be prevented by certain antioxidant metabolites present in plants. 
- Hepatoprotective Effect Of Alhagi maurorum Boiss (Leguminosae) Alcoholic Extract

\section{CONCLUSION}

Alhagi maurorum alcoholic extract effectively improved liver functions and protected against liver tissues damage induced by toxic substances. Alhagi maurorum has protective effect against the loss of antioxidant activities as result of oxidative process caused by $\mathrm{CCl} 4$ injection due to its phytochemicals compounds (phenloic and flavonids). This protective activity of Alhagi maurorum alcoholic extract suggests that regular consumption of it or food containing phenoilc and flavonoids may protect against liver disease and imbalanced antioxidant. Thus, the possibility that Alhagi maurorum reduce the risk of liver disease and oxidation process remains open and further longitudinal studies are needed to confirm the importance of it in the prevention of liver disease.

\section{REFERENCES}

- Al-Dosari, M. S. (2010): The Effectiveness of Ethanolic Extract of Amaranthus Tricolor L.: A Natural Hepatoprotective Agent, An International Journal of Comparative Medicine East and West, vol. 38(6).

- Allain, C. C., Poon, L. S., Chan, C. S. G., Richmand, W. A. and Fu, P. (1974) Enzymatic Determination of Total Serum Cholesterol, Clinical Chemistry, vol. 20: 470-5.

- Anila, L. and Vijayalakshmi, N.R. (2002):Flavonoids from Emblica officinalis and Mangifera indica - effectiveness for dyslipidaemia. J. Ethnopharmacol. 79, 81-87.

- Armitage, P. G., Berry, and Matthews, J.M.S. (2002):Statistical Methods in Medical Research. 4th Ed. Blackwell Science Ltd.

- Atta, A.H. and Abo El-Sooud, K.(2004): The antinociceptive effects of some Egyptian medicinal plants. J. Ethnopharmacol., 95 (2-3): 235-238.

- Awaad. A.S., Maitland, D.J. and Soliman, G.A. (2006): Antiulcerogenic activity of Alhagi maurorum. Pharmaceut. Biol 44 (4), 292-296.

- Baravalia, Y., Vaghasiya, Y. and Chanda, S. (2011) Hepatoprotective Effect of Woodfordia Fruticosa Kurz Flowers on Diclofenac Sodium Induced Liver Toxicity in Rats, Asian Pacific Journal of Tropical Medicine, vol. 4(5): 342-346. 
- Beata, O., Arafa, I.H., Wieslaw, O. and Anna, S. (2015): Comparison of biological activity of phenolic fraction from roots of Alhagi maurorumwith properties of commercial extract and resveratrol.; [Internet].Available from: www.tandfonline.com

- Bergmeyer, H.U.; Schreiber, P. and Wahlefeld, A.W. (1978):Optimization of methods for aspartate and alanine aminotransferases. Clin. Chem.; 24: 58-61.

- Bhattacharyya., D; Mukherjee, R; Pandit ,S; Das, N. and Sur TK (2003): Hepatoprotective effect of Himoliv, a polyherbal formulation. Indian $\mathbf{J}$ Pharmacol., 47: 435 - 440

- Burtis, C. A., Ashwood, E. R., Bruns, D. E. and Tietz, N. W. (2006) Textbook of clinical chemistry and molecular biology, St. Louis: Elsevier Saunders.

- Candasamy, M., Vudumula, V. R., Srikakulam, V. P. and Vallampatla, A. D. (2010): Protective Effect of Livactine against CCl4 and Paracetamol Induced Hepatotoxicity in Adult Wistar Rats, N. Am. J. Med. Sci., vol. 2(10): 491-495.

- Carleton, H. (1979) : Histological Techniques, 4th Edition, Oxford University New York, USA,Toronto.

- Djeridane, A.; Youssef, M.; Nadjemi, B.; Boutassouna, D.; Stocker, P. and Vidal, N. (2006): Antioxidant activity of some Algerian medicinal plant extracts containing phenolic compounds. Food Chem.; 97:654-660.

- El-Habibi, E. M., Sirag, H. M., and Edrees, G. M. (2009): Comparative Effect Between Chitosan and Chitosan-Cu Complex on Carbon-Tetrachloride (CCl4) Induced Liver Damage in Rats, The Egyptian Journal of Hospital Medicine, vol. 36: 397-405.

- Fossati, P.; Prencipe, L. and Berti, G. (1980): Use of 3, 5 dichloro-2-hydroxyl enzene sulfonic acid /4-amylphenazonechromogenic system in direct nzymatic assay of uric acid in serum and urine. Clin. Chem.; 26: 227-231.

- Friedewald, W.T.; Levy, R.I. and Frederickson, D.S. (1972): Estimation of plasma or serum low density lipoprotein cholesterol concentration without use of ultracentrifuge. Clin. Chem.; 18: 499-502.

- Ghane., M, Badiei., K, Mohammadi., A.H, Mallah., A.R(2008): Diuretic effect of Alhagi maurorumin Goat. Is tInternational Congress of Veterinary Pharmacology and Pharmaceutical Science,Tehran-Iran. 
- Hamed., A, Perrone., A, Mahalel., U, Oleszek., W, Stochmal., A, Piacente., S(2012): Oleanane glycosides from the roots of Alhagi maurorum. Phytochem Lett 5(4):782-787.

- Harborne, J. B.( 2007): Phytochemical Methods: A Guide to Modern, Techniques of Plant Analysis, Chapman \& Hall, London, UK.

- Husdan, H. and Rapoport, A. (1968): Estimation of creatinine by Jaffe reaction method. Clin. Chem.; 14: 222-228.

- Hussein, S.M. , AL Hussein, T.M., Sedigheh, A. and Naderi, G.H. (2006) : Hepoatoprotictive effect of silybum marianum and calendula officinalis polyphenolic extracts in rats_, Journal of Food and Nutrition Research, vol. 52(2): 101-106.

- Ismet, Y., Ismail, T., Sule, G. and Zumrut, D. (2013): The Effects of Apricot on Serum Proteins and Liver Enzymes in Rats, Journal of Food and Nutrition Research, vol. 52(2): 101-106.

- Jalil ,R., Naveed A, khan Y, Khalil A, MukhtiarA,Sabira S, Hafiz MA(2015): Phytochemical Screening and Hepatoprotective Effect of Alhagi maurorumBoiss (Leguminosae) Against Paracetamol-Induced Hepatotoxicity in Rabbits. Tropical Journal of Pharmaceutical Research.; [Internet]. Available from: www.tjpr.org/admin.

- Khan, M.R. and Ahmed, D. (2009) :Protective effects of Digera muricata (L) Mart On testis against oxidative stress of carbon tetrachloride in rat .J Food Chem Toxicol .47:1393-1399.

- Kanchana, P., and Nuannoi ,C.( 2012): Comparison of the Antioxidant and Cytotoxic activities of Phyllanthus virgatus and Phyllanthus amarus Extracts. Med. Princ.. Pract 21:24-29.

- Khan, R. A., Khan, M. R., Sahreen, S., Jan, S., Bokhari, J. and Rashed, U. (2011) Prevention of $\mathrm{CCl} 4$ Induced Adrenal oxidative Stress in Rat by Sonchusasper, Journal of Medicinal Plants Research, vol. 5 (15): 3347-3350.

- Krasteva, A.Z.; Mitcheva, M.K.; Kondeva-Burdina, M.S. and Descatoire, V.A. (2007): In vitro study of lovastatin interactions with amiodarone and with carbon tetrachloride in isolated rat hepatocytes. World J. Gastroenterol., 13(15): 2198-204. 
- Laghari ,A.H., Memon,S., Nelofar,N. and. Khan,K.M.(2011): “Alhagi maurorum: a convenient source of lupeol," Industrial Crops and Products, vol. 34, no. 1, pp. 1141-1145.

- Lei., J.I.A. (2008): The active components in the Alhagi pseudalhagi seed oil relative to its physiological functions. J Gansu Agric Univ; 5: 38.

- Liu, C. M., Zheng, G. H., Ming, Q. L., Chao, C. and Sun, J. M. (2013) Sesamin Protects Mouse Liver against Nickel-Induced Oxidative DNA Damage and Apoptosis by the PI3K-Akt Pathway, J. Agric. Food Chem., vol. 61: 1146-1154.

- Lopes-Virella, M. F., Stone, P., Ellis S. and Colwell, J. A. (1977): Cholesterol Determination in High-Density Lipoproteins Separated by Three Different Methods, Clinical Chemistry, vol. 23(5): 882-4.

- Marashdah.,M.S and Hazimi., A.L (2010):Pharmacological activity of ethanolic extract ofAlhagi maurorumroots. Arabian journal of chemistry .Jan;3: [Internet] Availablefrom:www. sciencedirect.com/science/article.P. 3-42.

- Masuda, Y. (2006): Learning Toxicology from Carbon Tetrachloride-induced Hepatotoxicity. Journal of the Pharmaceutical Society of Japan., 126(10): 885-899.

- Mohammad, K.G.N. and Seyyed, A. (2007): Gastroprotective effect of Alhagi maurorumon experimental gastric ulcer in rats. Pakistan journal of medical science. professional medical publication; [Internet]. Available from: www.pjms.com.p.k/issue//julsep07/article

- Monica, R ,loizzo., khaled., R, Ataa., S, Marco., B, Francesco., M, Rosa., $\mathbf{T}(\mathbf{2 0 1 4})$ : Antiproliferative and antioxidant properties of Alhagi maurorum Boiss (Leguminosae) aerial parts. Industrial crops and products, 53; [Internet] Available from: www. sciencedirect.com.

- Mumoli., N, Cei., M, and Cosimi A (2006): Drug-related hepatotoxicity. N. Engl. J.Med. 354 (20): 2191-3.

- Neamah., N.F(2012): A Pharmacological evaluation of aqueous extract of Alhagi maurorum. Global J Pharmacol; 6(1):41-46.

- Ohkawa, H.; Ohahi, N. and Jadi, K. (1979): Assay for lipid peroxides in animal tissues by thiobarbituric acid reaction. Anal. Biochem; 95:351- 358. 
- Paglia, D.F. and Valentaine, W.N. (1979):Studies on glutathione and glutathione characterization of erythrocytes glutathione peroxidase. J. Lab. Clin. Med., 70:158-169.

- Park, S.W.; Lee, C.H.; Kim, Y.S.; Kang, S.S.; Jeon, S.J.; Son, K.H. and Lee, S.M. (2009): Protective Effect of Baicalin Against Carbon Tetrachloride-Induced Acute Hepatic Injury in Mice. J. Pharmacol Sci. Jan 11.

- Raju., R.W, Radhika., S.S, Kunal., Mahesh., T, Kalpana., S.P and Sunil., S.J.(2008): Screening of roots of Baliospermum montanum for hepatoprotective activity against paracetamol-induced liver damage in albino rats. Int. J. Green Pharm. October-December, 220-223.

- Ram., V. (2013): Protective role of Indian medicinal plants against liver damage. The Journal of Phytopharmacology 2(3): 1-3.

- Reeves, P.G.; Nielson, F.H., and Fahmy, G.C. (1993): Reports of the America Institute of Nutrition, adhoc wiling committee on the reformulation of the AIN93. Rodent Diet. J. Nutri., 123, 1939-1951.

- Riaz, S., Ahmed, N., Saleem, M., Jabbar, A., Nisar,R .and Ashraf., M. (2010): Antioxidant flavonoids from Alhagi maurorum. J Asian Nat Prod Res; 12(2):138-143.

- Rosenblat, M., Hayek, T. and Aviram, M. (2006) Anti-Oxidative Effects of Pomegranate Juice (pg) Consumption by Diabetic Patients on Serum and on Macrophages, Atheroscler, vol. 187(2): 363-371.

- Shaker, E., Mahmoud, H., Mnaa ,S. (2010): Anti-inflammatory and anti-ulcer activity of the extract from Alhagi maurorum(camelthorn).food and chemical toxicology. 48.

- Shnakumari, S., Nishanthini, A., Muthukumarasamy, S. and Mohan, V. R. (2012): Hepatoprotective and Antioxidant Activity of Canscora Perfoliata Lam (Gentianaceae) against CCl4 Induced Hepatotoxicity in Rats, International Journal of Research in Ayurveda and Pharmacy, vol. 3(6): 822-826.

- Sibe.,l .K. and Canan., K.(2005) : The protective effects of Achillea L. species native in Turkey against $\mathrm{H} 2 \mathrm{O} 2$-induced oxidative damage in human erythrocytes and leucocytes. J. Ethnopharmacol., 221-227. 
- Singal., A. and Kumar., V.I • (2009): Effect of aqueous suspension of dried latex of Calotropis procera on hepatorenal functions in rat. J.Ethnopharmacol., 122: 172-17.

- Sinha, K.A. (1972): Colorimetric assay of catalase enzyme. Anal. Biochem.; 47: 328-330.

- Spitz, D.R. and Oberley, L.W. (1989): An assay for superoxide dismutase activity in mammalian tissue homogenates. Anal. Biochem.; 179: 8-18.

- Sudhahar,v.; S. A. Kumar, Y. Mythili, and P. Varalakshmi, (2007): "Remedial effect of lupeol and its ester derivative on hypercholesterolemiainduced oxidative and inflammatory stresses," Nutrition Research,. 27(12) 778-787

- Sundaresan, S. and P. Subramanian (2003): S-allylcysteine inhibits circulatory lipid peroxidation and promotes antioxidants in N-nitrosodiethylamine-induced carcinogenesis. Pol. J. Pharmacol., 55: 37-42.

- Tavga, A. A., Zheen, A. A., Kasim, M. J., Munaf, H. A. and Saad, A. H. (2009): Study of the Protective Effects of Benfotiamine Against CCl4-Induced Hepatotoxicity in Rats, Iraqi J. Pharm. Sci., vol. 18.

- Trinder, P. (1969): Triglycerides Estimation by GPO-PAP Method, Annals of Clinical Biochemistry, vol. 6: 24-7.

- Vaziri, N. D., Wang, X. Q., Oveisi, F. and Rad, B. (2000): Induction of Oxidative Stress by Glutathione Depletion Causes Severe Hypertension in Normal Rats, Hypertension, vol. 36: 142-146.

- Xiao-feng,A., Jin,S., Jie ,R., Qian,M. and Yan-hua., L.u .(2011): The role of hepatoprotective effect of a flavonoid-rich extract of Salvia plebeia R.Br. on carbon tetrachlorideinduced acute hepatic injury in mice. J. Med. Plant. Res., 5(9): 1558-1563.

- Xu, D.; Wu, Y.; Liao, Z.X. and Wang, H. (2007): Protective effect of verapamil on multiple hepatotoxic factors-induced liver fibrosis in rats. Pharmacol. Res., 55(4): 280-6.

- Zalatnai, A., Sarosi, I., Rot, A. and Lapis, K. (1991) :Inhibitory and Promoting Effects of Carbon Tetrachloride- Induced Liver Cirrhosis on the Diethylnitrosamine Hepatocarcinogenesis in Rats, Cancer Lett., vol. 57: 67-73. 


\section{التأثير الوقائى للمستخلص الكمولى لنبات العاقول ضد التسمم الكبدي في الفئران}

* مايسةمحمد الملاح

الملخص العرببي

يعد نبـات العاقول مـن النبـاتات الطبيـة وذلك لاحتوائة على العديد مـن المركبـات الفينوليـة

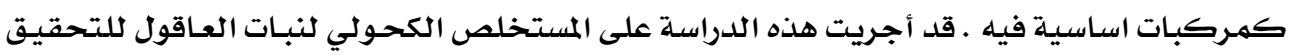

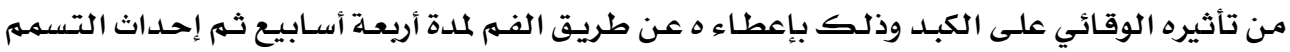

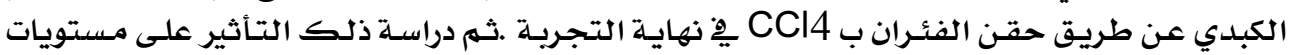

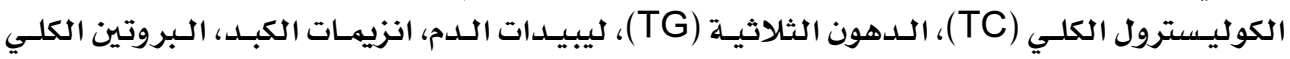

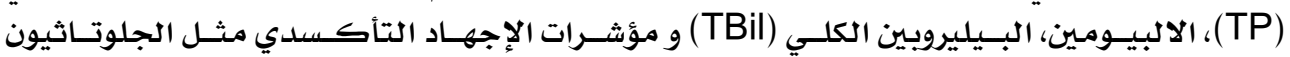

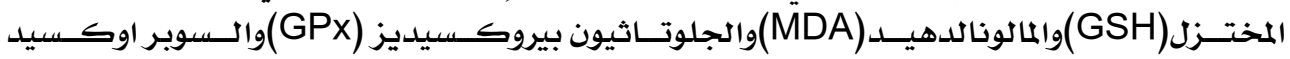

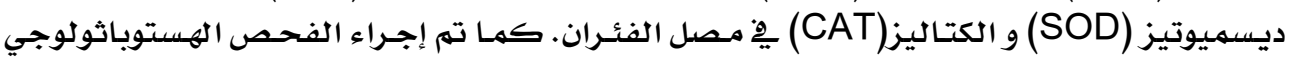

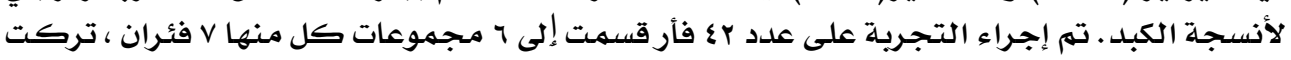

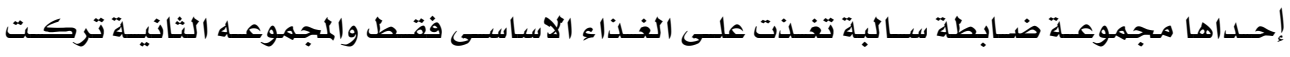

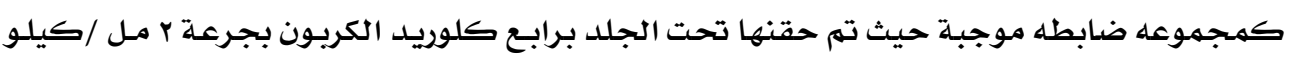

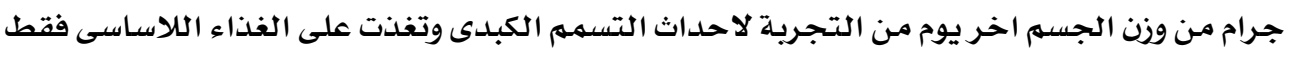

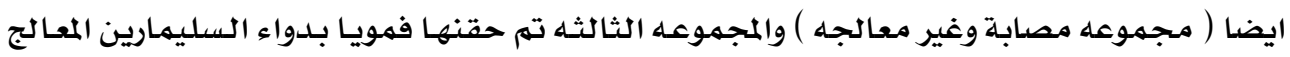

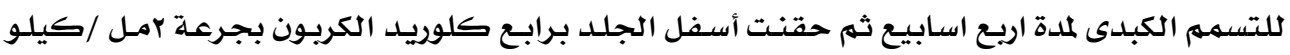

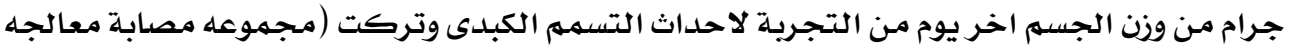

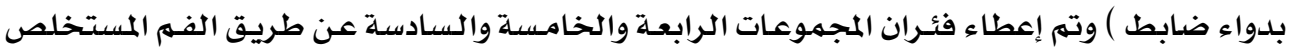

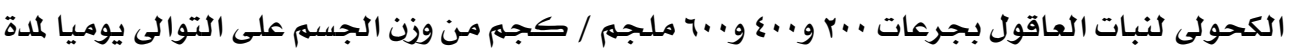

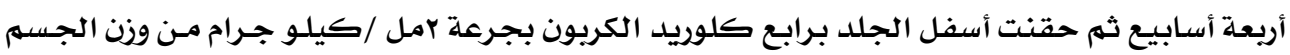

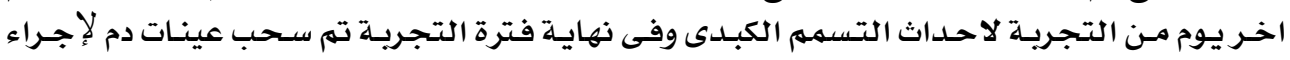

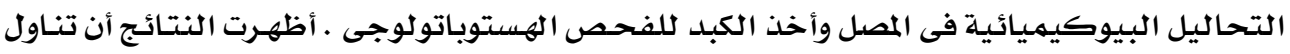

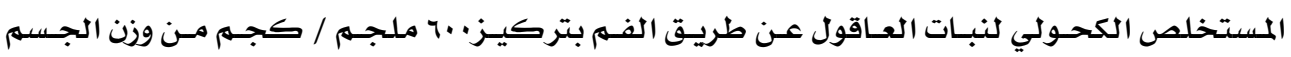

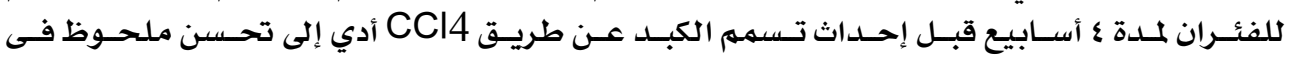

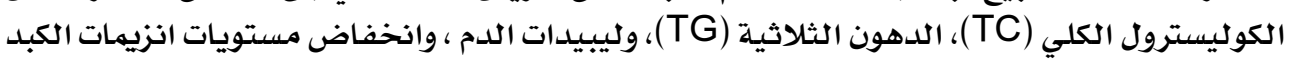

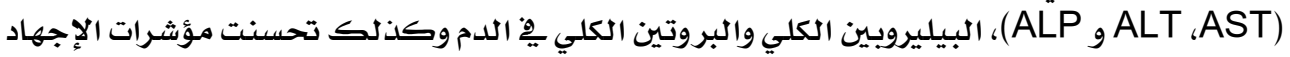

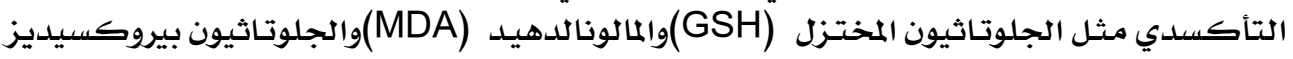

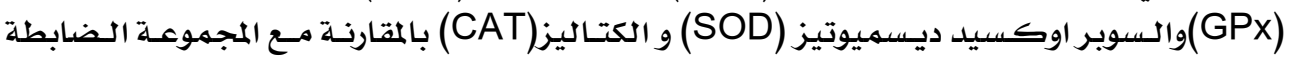

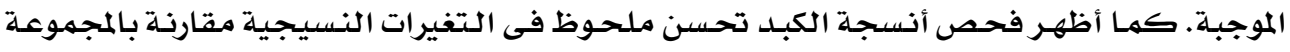
الضـابطة الموجبـة .وتوصى الدراسلة بـأن المستخلص الكحـولي لنبـات العـاقول لـه تأثير خـافض للسهون

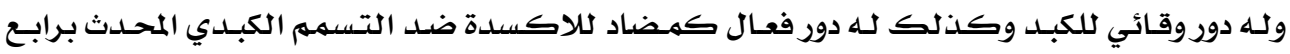

$$
\text { كلوريد الكريون . }
$$

قسم التغذية وعلوم الأطعمة - كلية الاقتصاد المنزلي - جامعة حلوان 